\title{
Hubungan Antara Perilaku Wajib Pajak Dan Kebijakan Pajak Berdasarkan Sudut Pandang Behavioral Accounting
}

\author{
Nina Septika Widyaningtyas ${ }^{1}$ \\ Fakultas Ekonomi dan Bisnis \\ Universitas Airlangga, Indonesia \\ Email: ninawidyaningtyas47@gmail.com
}

\begin{abstract}
ABSTRAK
Penelitian ini bertujuan untuk mengkaji dan mendeksripsikan hubungan antara perilaku wajib pajak dan kebijakan pajak berdasarkan sudut pandang behavioral accounting. Pendekatan penelitian yang digunakan adalah pendekatan kualitatif dengan menggunakan data sekunder yang dikumpulkan dari menggunakan studi literatur. Hasil penelitian menyatakan faktor yang mempengaruhi perilaku patuh wajib pajak dapat dibagi menjadi dua, yaitu faktor internal dan eksternal. Faktor internal adalah faktor yang berasal dari dalam diri wajib pajak, yang dapat berupa kepercayaan wajib pajak terhadap pemerintah dan hukum dan pengetahuan wajib pajak terhadap regulasi perpajakan. Faktor eksternal adalah faktor yang berasal dari luar diri wajib pajak, yang dapat berupa adanya penegakan sanksi pajak yang adil dan jelas dan pelaksanaan sosialisasi perpajakan oleh otoritas pajak. Hasil penelitian juga menyatakan bahwa peningkatan kepatuhan wajib pajak perlu menjadi sasaran dari kebijakan pajak pemerintah agar penerimaan pajak negara optimal.
\end{abstract}

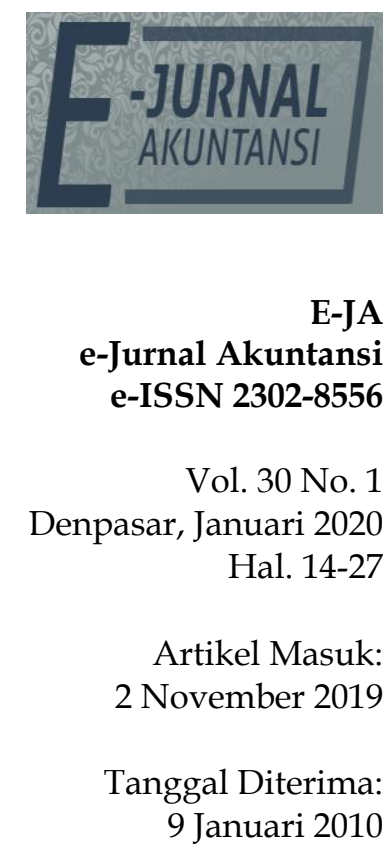

Kata Kunci: $\quad$ Perilaku Wajib Pajak; Kebijakan Pajak; Akuntansi Perilaku.

\section{Relationship Between Tax Mandatory Behavior And Tax Policy Based On Behavioral Accounting Perspective}

\begin{abstract}
This study aims to describe the relationship between taxpayer behavior and tax policy based on a behavioral accounting perspective. The used research approach is a qualitative approach by using collected secondary data from using literature studies. The results of the study stated that the factors, which influence taxpayer compliance behavior can be divided into two, namely internal and external factors. Internal factors are factors that originate from within the taxpayer, which can be in the form of a taxpayer's trust in the government and the taxpayer's law and knowledge of tax regulations. External factors are factors originating from outside the taxpayer themselves, which can be in the form of fair and clear tax sanctions and the implementation of tax socialization by the tax authority. The research results also stated that increasing taxpayer compliance needs to be the target of government tax policy in order to state tax revenue run optimally
\end{abstract}

Keywords: Taxpayer Behavior; Tax Policy; Behavioral Accounting. 


\section{PENDAHULUAN}

Anggaran untuk penyelenggaraan negara sebagian besar terpenuhi oleh penerimaan dari sektor pajak. Namun demikian, dalam kenyataannya pemerintah masih belum dapat mengoptimalkan penerimaan dari sektor pajak. Hal ini terlihat pada tax ratio Indonesia yang hanya 9,9\% pada tahun 2017, dimana nilai ini tergolong rendah untuk ukuran negara berkembang (Worldbank, 2019). Hingga 1 April 2019, Direktorat Jenderal Pajak Kementrian Keuangan menunjukkan catatan realisasi pelaporan Surat Pemberitahuan (SPT) Tahunan sejumlah 11.309 juta wajib pajak, baik wajib pajak pribdin maupun badan. Secara persentase, jumlah pelaporan SPT setara 61,7\% dari total wajib pajak yang seharusnya melaporkan SPT Tahunan yang sebesar 18.334 juta (Uli, 2019). Nilai tax ratio yang rendah dan persentase jumlah wajib pajak yang rendah menunjukkan kepatuhan wajib pajak yang masih rendah (Farouq, 2018).

Kepatuhan wajib pajak adalah kesediaan dari wajib pajak untuk mentaati seluruh peraturan perpajakan yang diterapkan pemerintah (Wicaksono, Nazar, dan Kurnia, 2018). Kepatuhan adalah bentuk perilaku aktif dari wajib pajak, utamanya dalam hal memenuhi kewajiban pajak yang dibebankan kepadanya (Susanto, 2002). Oleh karena itu, pemerintah melakukan berbagai kebijakan untuk dapat mendorong semakin meningkatnya kepatuhan wajib pajak, antara lain dengan mempermudah proses pembayaran pajak dengan menggunakan sarana elektronik (e-filling), dan memberikan pengampunan denda pajak melalui program pemutihan pajak (Syakura dan Yoremia, 2017).

Pajak sendiri dapat diartikan sebagai pembayaran yang dilakukan oleh rakyat kepada negara sesuai dengan regulasi terkait dengan tidak mendapatkan imbalan secara langsung (Mardiasmo, 2009). Meskipun demikian, pajak sebenarnya diperuntukkan kepada rakyat karena digunakan oleh negara untuk membiayai penyelenggaraan negara dan untuk membangun fasilitas publik. Menurut Pasal 1 ayat 1 Undang-Undang Republik Indonesia No. 28 Tahun 2007 tentang Perubahan Ketiga atas Undang-Undang Nomor 6 Tahun 1983 Tentang Ketentuan Umum dan Tata Cara Perpajakan, pajak dapat dijelaskan sebagai kontribusi wajib kepada negara yang terutang oleh orang pribadi atau badan yang bersifat memaksa berdasarkan Undang-Undang, dengan tidak mendapatkan imbalan secara langsung dan digunakan untuk keperluan negara bagi sebesar-besarnya kemakmuran rakyat.

Kebijakan pajak merupakan salah satu bentuk dari kebijakan publik. Oleh karena itu, penetapan kebijakan pajak dilakukan dengan mengacu pada penetapan kebijakan publik. Pengertian kebijakan publik dijelaskan dalam Peraturan Menteri Negara Pendayagunaan Aparatur Negara No. Per/04/M.PAN/4//2007 tentang Pedoman Umum Formulasi, Implementasi, Evaluasi Kinerja, dan Revisi Kebijakan Publik di Lingkungan Lembaga Pemerintah Pusat dan Daerah adalah dengan merinci pengertian dari istilah pembentuknya, yaitu kebijakan dan publik. Kebijakan adalah keputusan yang dibuat oleh suatu lembaga pemerintahan atau organisasi dan bersifat mengikat para pihak yang terkait dengan lembaga tersebut. Publik adalah hal-ikhwal yang berkaitan dengan kepentingan orang banyak atau masyarakat luas. Dengan demikian, kebijakan publik adalah keputusan yang dibuat oleh pemerintah atau lembaga pemerintahan untuk mengatasi permasalahan tertentu, untuk 
melakukan kegiatan tertentu atau untuk mencapai tujuan tertentu yang berkenaan dengan kepentingan dan manfaat orang banyak.

Menurut Rabin (2003), kebijakan publik adalah program tentang tindakan, aksi, atau kegiatan yang dirancang untuk mencapai keberhasilan tertentu atau tujuan spesifik dengan melibatkan semua tingkat perangkat pemerintahan sebagai pelaku formal maupun informal. Dengan demikian terdapat beberapa aspek penting yang harus dipahami pada kebijakan publik, yaitu dibuat oleh pemerintah; memiliki tujuan spesifik, misalnya untuk mengatasi suatu permasalahan; dan untuk memberi manfaat kepada publik.

Berdasarkan tujuan yang ingin dicapai, maka penetapan kebijakan pajak sebagai bagian dari kebijakan publik perlu mengacu pada permasalahan yang sedang dihadapi publik. Menurut Hallsworth, Parker, dan Rutter (2011), penetapan kebijakan publik mencakup dua tahapan besar, yaitu formulasi masalah dan penetapan kebijakan. Formulasi masalah merupakan tahapan yang dilakukan dengan tujuan untuk mengetahui permasalahan yang sedang dihadapi, penyebab dari munculnya permasalahan tersebut, dan kedudukan pemerintah dalam mengatasi masalah tersebut. Tahapan penetapan kebijakan meliputi upaya untuk mengumpulkan dan menganalisis informasi yang berhubungan dengan masalah yang bersangkutan, kemudian berusaha mengembangkan alternatif kebijakan, membangun dukungan dan melakukan negosiasi, sehingga sampai pada sebuah kebijakan yang akan dipilih.

Pemungutan pajak yang dilakukan oleh pemerintah juga berkaitan dengan perilaku wajib pajak. Sebagaimana diketahui bahwa perilaku wajib pajak mencakup seluruh respon yang berasal dari diri wajib pajak terhadap regulasi perpajakan yang diterapkan pemerintah. Secara garis besar, respon tersebut dapat berupa respon yang bersifat pasif maupun aktif. Respon pasif dapat berupa pemikiran, perasaan, maupun sikap dari wajib pajak, yang umumnya tidak dapat diamati secara langsung. Berbeda dengan respon pasif, maka respon aktif dari wajib pajak merupakan bentuk perilaku yang dapat diamati. Respon aktif wajib pajak dapat berupa tingkat kepatuhan wajib pajak dalam membayar pajak sesuai dengan ketentuan pemerintah (Susanto, 2002).

Kepatuhan wajib pajak sebagai bentuk perilaku aktif adalah indikator penting yang diukur oleh pemerintah untuk mengetahui jumlah penerimaan pajak negara. Kepatuhan wajib pajak sangat penting untuk dapat mendorong peningkatan jumlah penerimaan pajak negara. Oleh karena itu, pemerintah melakukan berbagai kebijakan untuk dapat mendorong semakin meningkatnya kepatuhan wajib pajak, antara lain dengan mempermudah proses pembayaran pajak dengan menggunakan sarana elektronik (e-filling), dan memberikan pengampunan denda pajak melalui program pemutihan pajak (Syakura dan Yoremia, 2017).

Menurut Theory of Planned Behavior (TPB), kepatuhan wajib pajak dapat dipengaruhi oleh faktor sikap, subjective norm, dan perceived behavioral control (Ajzen dan Fishbein, 1975). Behavioral belief merupakan keyakinan dan evaluasi terhadap perilaku tertentu yang menghasilkan informasi untuk membentuk sikap terhadap perilaku tersebut. Sikap merujuk pada perasaan atau kecenderungan untuk ingin atau tidak ingin berperilaku, dan atau mendukung atau tidak mendukung suatu jenis perilaku. Normative belief merupakan 
keyakinan terhadap suatu perilaku berdasarkan referensi dari lingkungan, baik yang berasal dari teman, keluarga, atau pihak lain yang dianggap penting pendapatnya. Keyakinan tersebut membentuk norma subjektif, yaitu nilai yang dijadikan acuan berperilaku berdasarkan pengaruh dari lingkungan sekitar. Control belief adalah keyakinan terhadap keberadaan faktor-faktor pendukung dan penghambat untuk berperlaku tertentu. Keyakinan ini menjadi dasar terbentuknya perceived behavioral control, yaitu persepsi individu terhadap kemampuannya dalam beperilaku tertentu (Ajzen dan Fishbein, 1975).

Dalam upaya meningkatkan penerimaan pajak negara, kepatuhan wajib pajak merupakan salah satu faktor yang perlu untuk selalu diperhatikan oleh pemerintah. Hal ini disebabkan karena perilaku aktif wajib pajak tersebut dapat dijadikan sebagai data penting untuk merumuskan kebijakan pajak yang paling tepat. Menurut konsep akuntansi keperilakuan, informasi yang dibutuhkan untuk pengambilan keputusan tidak hanya berupa data kuantitatif, namun perlu juga dilengkapi dengan data kualitatif yang berasal dari perilaku wajib pajak (Suartana, 2012). Dengan kata lain, akuntansi keperilakuan menyediakan informasi tambahan dari sisi non finansial yang melengkapi kebutuhan informasi dari pengambil keputusan (Supriyono, 2018).

Berdasarkan teori atribusi, faktor-faktor yang menyebabkan perilaku seseorang dalam teori akuntansi keperilakuan dapat dilihat melalui aspek internal dan eksternal. Artinya, seseorang berperilaku tertentu karena mungkin ada pengaruh faktor-faktor yang berasal dari dalam diri atau dari luar dirinya (Robbins dan Judge, 2008). Faktor internal dapat berupa sikap, karakter, pengetahuan, keterampilan, atau sifat, sedangkan faktor eksternal dapat berupa lingkungan sekitar atau situasi tertentu yang mendorong seseorang untuk berperilaku yang sesuai (Heider, 1958).

Analisis terhadap perilaku tidak hanya dapat menghasilkan informasi yang menggambarkan mengenai karakteristik yang dimiliki, namun juga dapat digunakan untuk menghasilkan prediksi atau estimasi terhadap perilaku dalam suatu situasi tertentu. Dengan demikian, teori atribusi memiliki peran penting untuk digunakan dalam mengeksplorasi informasi yang dibutuhkan dalam suatu pengambilan keputusan bisnis (Luthans, 2005).

Pada penelitian yang telah dilakukan oleh Anggraini (2015) dijelaskan bahwa terdapat tiga faktor yang dapat mempengaruhi kepatuhan wajib pajak dalam mematuhi setiap kebijakan pajak yang dilakukan. Faktor yang dimaksud adalah perilaku wajib pajak, motivasi, dan iklim organisasi. Perilaku wajib pajak sendiri merupakan salah satu faktor yang dijelaskan dalam theory of planned behavior yang dapat menunjukkan sikap mendukung atau menolak sebuah kebijakan pajak. Motivasi dijelaskan sebagai dorongan yang dialami oleh wajib pajak yang dapat ditimbulkan dari keyakinan terhadap faktor pendukung kebijakan pajak, dan iklim organisasi merupakan bagian dari faktor pendukung kebijakan pajak yang dimaksud.

Sebelumnya Siat dan Toly (2013) juga menjelaskan bahwa kepatuhan wajib pajak dapat didorong oleh empat faktor, yaitu hukum pajak, sikap rasional, kesadaran wajib pajak, dan faktor petugas pajak. Keempat faktor ini memiliki peran untuk mendukung wajib pajak dalam menunjukkan perilaku yang patuh terhadap setiap kebijakan pajak yang diberlakukan. Hukum pajak 
yang tegas dengan dibantu oleh petugas yang kompeten dan tingkat kesadaran wajib pajak untuk membayar pajak yang tinggi dengan didukung sikap yang rasional dapat mendukung peningkatan penerimaan pajak negara. Namun menurut penelitian yang dilakukan oleh Febriyani dan Kusmuriyanto (2015), sikap wajib pajak justru tidak berpengaruh terhadap tingkat kepatuhan yang ditunjukkan wajib pajak pada setiap kebijakan pajak. Hasil penelitian yang sama juga dijelaskan oleh Razak dan Adafula (2013) yang mengungkapkan bahwa wajib pajak akan cenderung menunjukkan tingkat kepatuhan yang baik terhadap kebiajkan pajak ketika wajib pajak mengerti tentang peraturan pajak yang berlaku. Lebih lanjut dijelaskan oleh Razak dan Adafula (2013) bahwa mayoritas wajib pajak cenderung tidak mengerti tentang peraturan pajak, sehingga tingkat kepatuhan menjadi rendah.

Berdasarkan penjelasan di atas, dapat dijelaskan bahwa setiap kebijakan pajak yang diberlakukan perlu memperoleh dukungan oleh wajib pajak untuk dapat optimal dalam pelaksanaan dan memberikan manfaat pada penerimaan negara. Namun dilain sisi, dukungan wajib pajak dalam bentuk sikap khususnya cenderung masih kurang karena wajib pajak masih cenderung pasif atau kurang peduli dengan peraturan pajak yang berlaku. Oleh karena itu penelitian ini dilaksanakan dengan tujuan untuk mengkaji dan mendeksripsikan hubungan antara perilaku wajib pajak dan kebijakan pajak berdasarkan sudut pandang behavioral accounting.

\section{METODE PENELITIAN}

Penelitian ini menggunakan metode kualitatif deskriptif. Menurut Istijanto (2010), metode kualitatif adalah metode yang digunakan untuk mengeksplorasi dan memahami makna dari permasalahan atau topik yang diteliti. Proses penelitian kualitatif ini melibatkan upaya-upaya penting, seperti mengumpulkan data yang spesifik dari berbagai sumber data, menganalisis data secara induktif mulai dari tema-tema yang khusus ke tema-tema umum, dan menafsirkan makna data. Peneliti harus menerapkan cara pandang penelitian yang bergaya induktif, berfokus terhadap makna data, dan menerjemahkan kompleksitas suatu persoalan. Selain itu, penelitian yang dilakukan juga merupakan penelitian deskriptif, yaitu penelitian yang memberikan penjelasan berdasaran data penelitian yang berupa serangkaian bahasa dalam bentuk teks. Menurut Wibowo (2011), melaksanakan penelitian deskriptif memerlukan pemiiran yang terbuka dengan wawasan yang luas disertai tingkat sensitifitas yang tinggi dalam melakukan analisa topik penelitian dan mengintepretasikan data yang diperoleh melalui deskripsi ke bentuk penjelasan yang jelas, kritis, dan relevan.

Data penelitian ini berupa data sekunder, yaitu data yang diperoleh tidak dari sumbernya secara langsung. Peneliti memperoleh data sekunder dari pihak lain yang telah secara langsung mengumpulkan data dari sumber data, dengan demikian, peneliti menjadi pihak kedua yang memperoleh data setelah pihak pertama yang menjadi pengumpul data langsung (Moleong, 2012). Data tersebut dikumpulkan menggunakan studi literatur, yaitu dengan menelusuri data-data internet yang memiliki relevansi dengan topik penelitian. Analisis data dilakukan menggunakan teknik kualitatif, yaitu dengan cara melakukan telaah 
terhadap data penelitian, kemudian mengurangi data-data yang tidak relevan, dan melakukan interpretasi serta menarik kesimpulan (Rabin, 2003).

\section{HASIL DAN PEMBAHASAN}

Analisis terhadap perilaku wajib pajak utamanya adalah terkait dengan perilaku yang secara nyata dapat diketahui keterhubungannya dengan sistem perpajakan, yaitu dalam bentuk kepatuhan wajib pajak dalam membayar kewajiban pajaknya sesuai dengan regulasi perpajakan yang berlaku. Jika mengacu pada data Kementrian Keuangan dan Direktorat Jenderal Pajak, dapat diketahui bahwa tingkat kepatuhan pajak masyarakat Indonesia menunjukkan trend positif dari tahun ke tahun sebagaimana dapat dilihat pada data pada Gambar 1.

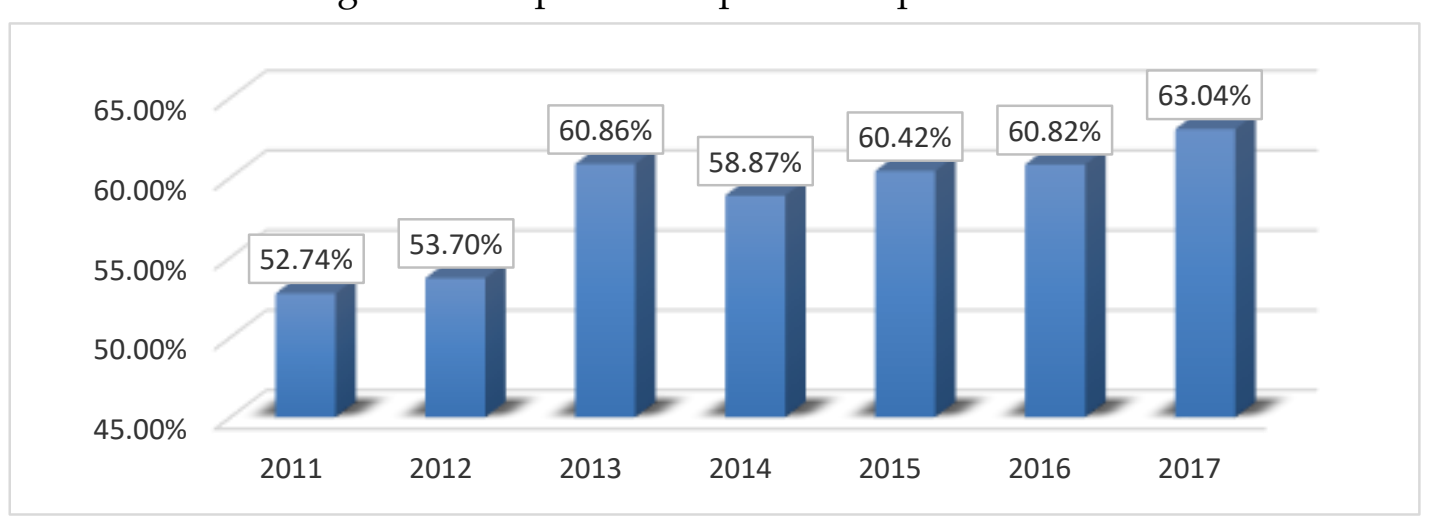

Gambar 1. Tingkat Kepatuhan Wajib Pajak Periode 2011-2017

Sumber: Kementrian Keuangan Republik Indonesia, 2018

Data di atas menunjukkan bahwa tingkat kepatuhan wajib pajak terendah adalah pada tahun 2011, yaitu sekitar 52,74\%, yang kemudian meningkat menjadi $53,70 \%$ pada tahun 2012. Tingkat kepatuhan ini selanjutnya mengalami peningkatan signifikan pada tahun 2013 menjadi 60,86\%, namun pada tahun berikutnya justru menurun menjadi $58,87 \%$ di tahun 2014 . Kepatuhan pajak kembali menunjukkan peningkatan pada tahun 2015 menjadi 60,42\%, kemudian meningkat lagi menjadi $60,82 \%$ di tahun 2016, dan terakhir meningkat menjadi $63,04 \%$ di tahun 2017. Trend positif ini menunjukkan bahwa kesadaran masyarakat Indonesia terhadap kewajibannya membayar pajak semakin baik, apalagi dalam keadaan jumlah wajib pajak yang semakin bertambah dari tahun ke tahun sebagaimana data Kementrian Keuangan dan Direktorat Jenderal Pajak.

Tabel 1. Pertumbuhan Jumlah Wajib Pajak

\begin{tabular}{ccccc}
\hline \multirow{2}{*}{ Tahun } & \multirow{2}{*}{ Jumlah Wajib Pajak } & \multicolumn{3}{l}{ Proporsi Perjenis Wajib Pajak Terdaftar } \\
\cline { 3 - 5 } & & $\begin{array}{l}\text { Orang } \\
\text { Pribadi }\end{array}$ & Badan & Bendahara \\
\hline 2014 & 30.574 .428 & $90,56 \%$ & $8,09 \%$ & $1,35 \%$ \\
2015 & 33.336 .122 & $90,60 \%$ & $8,05 \%$ & $1,36 \%$ \\
2016 & 36.446 .616 & $90,66 \%$ & $8,01 \%$ & $1,33 \%$ \\
2017 & 39.151 .603 & $90,78 \%$ & $7,95 \%$ & $1,28 \%$ \\
\hline
\end{tabular}

Sumber: Kementrian Keuangan Republik Indonesia, 2018

Data pada Tabel 1. menunjukkan bahwa peningkatan jumlah wajib pajak terjadi secara berkelanjutan, yaitu dari 30, 574 juta pada tahun 2014 hingga menjadi 39,151 juta pada tahun 2017. Dapat diketahui juga bahwa menurut 
proporsi, peningkatan ini terjadi secara terus menerus hanya pada wajib pajak orang pribadi, sedangkan wajib pajak badan justru terus menerus mengalami penurunan jumlahnya dan wajib pajak bendahara mengalami fluktuasi.

Peningkatan kepatuhan pajak yang ditunjukkan oleh peningkatan rasio kepatuhan dan jumlah wajib pajak terdaftar di atas ternyata masih belum diimbangi oleh peningkatan dalam rasio pajak. Menurut data world bank, rasio pajak masih berada pada tingkat yang cukup rendah untuk ukuran negara berkembang. Bahkan rasio pajak Indonesia juga masih berada di level bawah dibandingkan negara-negara ASEAN lainnya.

Tabel 2. Tax Ratio Indonesia dibanding Negara ASEAN Lainnya

\begin{tabular}{llllllll}
\hline Negara & 2011 & 2012 & 2013 & 2014 & 2015 & 2016 & 2017 \\
\hline Thailand & $16,36 \%$ & $15,44 \%$ & $17,29 \%$ & $15,94 \%$ & $16,28 \%$ & $15,4 \%$ & $14,8 \%$ \\
Filipina & $12,38 \%$ & $12,89 \%$ & $13,31 \%$ & $13,61 \%$ & $13,63 \%$ & $13,7 \%$ & $14,2 \%$ \\
Malaysia & $14,79 \%$ & $15,61 \%$ & $15,31 \%$ & $14,84 \%$ & $14,30 \%$ & $13,8 \%$ & $13,1 \%$ \\
Singapura & $13,28 \%$ & $13,85 \%$ & $13,49 \%$ & $13,85 \%$ & $13,63 \%$ & $13,7 \%$ & $14,8 \%$ \\
Indonesia & $11,12 \%$ & $11,38 \%$ & $11,29 \%$ & $10,84 \%$ & $10,75 \%$ & $10,3 \%$ & $9,9 \%$ \\
\hline
\end{tabular}

Sumber: Worldbank, 2019

Data pada Tabel 2. tidak hanya menunjukkan bahwa Indonesia termasuk negara dengan tax ratio terendah dibandingkan negara ASEAN lain, tapi juga menunjukkan adanya penurunan tax ratio di Indonesia secara berkelanjutan dari tahun ke tahun. Tax ratio adalah persentase perbandingan antara produk domestik bruto dengan penerimaan pajak, yang sering disebut juga sebagai salah satu indikator kinerja pemerintah dalam memungut pajak (Farouq, 2018). Oleh karena itu, tax ratio yang rendah menunjukkan kurang optimalnya kinerja pemerintah dalam memungut pajak dan juga kepatuhan wajib pajak yang sebenarnya dapat lebih ditingkatkan lagi.

Sebagai sebuah negara berkembang, Indonesia juga mengalami beragam permasalahan terkait pemungutan pajak. Menurut Listyowati, Samrotun, dan Suhendro (2018), permasalahan tersebut utamanya disebabkan karena administrasi perpajakan yang masih lemah, sehingga memungkinkan terjadinya korupsi, penggelapan pajak, atau adanya pungutan liar kepada masyarakat. Administrasi pajak yang lemah akan menyebabkan rendahnya efisiensi proses pemungutan pajak, yang pada akhirnya akan menjadi penyebab rendahnya kepatuhan dari wajib pajak. Selain dipengaruhi oleh faktor kelemahan administrasi pemerintah, rendahnya kepatuhan wajib pajak juga dapat dipengaruhi oleh faktor-faktor lain, seperti kekurang-jelasan undang-undang perpajakan yang berlaku, kurangnya sarana untuk mengakses informasi perpajakan yang dibutuhkan wajib pajak, rendahnya pendapatan, sikap wajib pajak, budaya atau norma ketidakpatuhan yang ada di masyarakat, atau kurangnya pengetahuan wajib pajak tentang regulasi perpajakan.

Menurut penelitian oleh Wicaksono, Nazar, dan Kurnia (2018), kepatuhan wajib pajak dapat dipengaruhi oleh pengetahuan wajib pajak, kualitas pelayanan, dan sanksi perpajakan. Pengetahuan wajib pajak adalah berbagai hal yang berkaitan dengan regulasi perpajakan yang diketahui oleh wajib pajak. Semakin tinggi pengetahuan wajib pajak, maka semakin tinggi juga tingkat kepatuhan wajib pajak. Berdasarkan hal ini, maka edukasi terkait peraturan 
perpajakan kepada wajib pajak dapat menjadi alternatif solusi yang dapat diterapkan untuk mendorong peningkatan kepatuhan wajib pajak.

Kepatuhan wajib pajak juga dapat dipengaruhi oleh kualitas layanan dari kantor pajak, dimana semakin baik kualitas layanan pajak yang diterima oleh wajib pajak, maka kepatuhan wajib pajak akan semakin meningkat juga. Sesuai dengan Pasal 1 ayat 1 Undang-Undang No. 25/2009 tentang pelayanan publik, maka layanan pajak yang berkualitas adalah layanan yang mampu memenuhi kebutuhan wajib pajak atas berbagai hal yang berkaitan dengan perpajakan, seperti ketersediaan informasi, kemudahan prosedur, transparansi pajak, atau efektivitas proses pelayanan.

Ketidakpatuhan wajib pajak akan berkurang jika terdapat sanksi perpajakan yang ditegakkan dengan tegas. Dalam hal ini terdapat dua hal penting untuk dapat membuat sanksi perpajakan mampu mendorong peningkatan kepatuhan wajib pajak, yaitu kejelasan sanksi dan keadilan penegakkan sanksi. Kejelasan sanksi merujuk pada perumusan peraturan perpajakan yang menjelaskan mengenai sanksi-sanksi yang akan diterima oleh wajib pajak jika tidak patuh terhadap peraturan perpajakan. Wajib pajak harus mengetahui dengan jelas, bahwa sanksi yang akan diterima dapat lebih merugikan wajib pajak daripada membayar pajak. Keberadaan sanksi perpajakan yang jelas juga harus ditegakkan dengan adil, yaitu dengan tidak membeda-bedakan status atau jenis wajib pajak.

Faktor lain yang dapat mempengaruhi kepatuhan wajib pajak adalah adanya tax amnesty. Hal ini dibuktikan oleh Rahayu (2017) dalam penelitiannya yang menemukan bahwa tax amnesty berpengaruh positif signifikan terhadap kepatuhan wajib pajak. Artinya, kebijakan pemerintah untuk memberikan tax amnesty dapat mendorong wajib pajak untuk semakin mematuhi peraturan perpajakan. Menurut Undang-Undang No 11/2016, tax amnesty adalah kebijakan pemerintah yang menghapus pajak terutang dari wajib pajak, serta menghilangkan sanksi-sanksi perpajakan kepada wajib pajak yang bersedia secara sukarela mengungkap hartanya dan membayar uang tebusan.

Faktor lain yang juga mempengaruhi kepatuhan wajib pajak menurut Primasari (2016) adalah kepercayaan wajib pajak dan sosialisasi perpajakan. Wajib pajak dapat menjadi lebih patuh terhadap regulasi perpajakan jika wajib pajak memiliki keyakinan bahwa sistem hukum dan pemerintahan diselenggarakan berdasarkan pada prinsip keadilan dan kebenaran. Prinsipprinsip tersebut menjadi dasar pertimbangan wajib pajak bahwa uang pajak yang dibayarkan benar-benar akan dipergunakan untuk penyelenggaraan negara dan pembagunan fasilitas publik, bukan untuk kepetingan pihak-pihak tertentu saja. Selain dipengaruhi oleh kepercayaan, kepatuhan wajib pajak dapat semakin meningkat jika wajib pajak memahami dan menyadari pentingnya pajak bagi negara. Pemahaman dan kesadaran tersebut dapat tercipta jika otoritas pajak melakukan berbagai upaya sosialisasi yang efektif dan tepat sasaran, yang pada akhirnya akan mendorong semakin patuhnya wajib pajak terhadap regulasi perpajakan yang berlaku.

Jika mengacu pada Theory of Planned Behavior (TPB), maka kepatuhan wajib pajak sebagai bentuk perilaku aktif secara umum dapat dipengaruhi oleh tiga faktor utama, yaitu sikap, subjective norm, dan perceived behavioral control 
(Ajzen dan Fishbein, 1975). Ketiga faktor tersebut terbentuk berdasarkan aspek keyakinan atau kepercayaan, sehingga sesuai dengan temuan Primasari (2016) di atas, maka faktor kepercayaan wajib pajak terhadap sistem hukum dan negara sebenarnya merupakan faktor utama yang mampu mendorong peningkatan kepatuhan wajib pajak. Setelah wajib pajak memiliki kepercayaan terhadap pemerintah, bahwa pajak yang dibayarkan akan digunakan untuk kepentingan masyarakat, maka wajib pajak akan memiliki sikap yang mencerminkan kepatuhan terhadap regulasi perpajakan. Sebaliknya, jika wajib pajak memiliki rasa tidak percaya kepada pemerintah, maka sikap yang terbentuk akan mencerminkan ketidakpatuhan terhadap regulasi perpajakan. Faktor yang menentukan kecenderungan sikap wajib pajak adalah pengetahuan wajib pajak, yang sangat tergantung pada upaya otoritas pajak dalam melakukan sosialisasi atas berbagai hal yang berkaitan dengan perpajakan.

Perilaku patuh wajib pajak juga dapat dipengaruhi oleh faktor subjective norms, yaitu bagaimana lingkungan di sekitar mempengaruhi wajib pajak untuk patuh atau justru untuk tidak patuh. Hal ini sangat tergantung pada bagaimana lingkungan di sekitar wajib pajak mempersepsikan pajak, baik terkait dengan manfaat pajak atau kerugian-kerugian yang dapat diterima jika tidak mematuhi hukum pajak. Dalam hal ini, penegakan sanksi perpajakan yang jelas dan adil menjadi salah satu faktor penting yang mampu menciptakan nilai kepatuhan di lingkungan wajib pajak, yang pada akhirnya akan dapat mempengaruhi wajib pajak untuk patuh.

Faktor ketiga yang mempengaruhi perilaku patuh wajib pajak menurut TPB adalah perceived behavioral control, yaitu persepsi wajib pajak mengenai kemampuannya untuk mengurus perpajakannya sendiri dan membayar kewajiban pajak sesuai peraturan yang berlaku. Persepsi ini dapat terbentuk jika wajib pajak memiliki pengetahuan mengenai perpajakan, dimana hal tersebut memerlukan peran aktif dari otoritas pajak melalui sosialisasi perpajakan.

Jika mengacu pada teori atribusi, maka faktor yang mempengaruhi perilaku patuh wajib pajak dapat dibagi menjadi dua, yaitu faktor internal dan faktor eksternal. Faktor internal adalah faktor yang berasal dari dalam diri wajib pajak, yang dapat berupa kepercayaan wajib pajak terhadap pemerintah dan hukum dan pengetahuan wajib pajak terhadap regulasi perpajakan. Faktor eksternal adalah faktor yang berasal dari luar diri wajib pajak, yang dapat berupa adanya penegakan sanksi pajak yang adil dan jelas dan pelaksanaan sosialisasi perpajakan oleh otoritas pajak.

Sebagaimana dikemukakan oleh Luthans (2005), bahwa pemahaman terhadap faktor-faktor yang mempengaruhi perilaku patuh wajib pajak sangat penting untuk dapat mengetahui karakteristik wajib pajak dan memprediksi perilaku wajib pajak pada keadaan tertentu. Jika pemahaman ini diintegrasikan dengan pengetahuan atas tingkat kepatuhan wajib pajak yang ada, maka pemerintah dapat merumuskan strategi dan kebijakan pajak yang paling tepat untuk dapat mendorong peningkatan kepatuhan wajib pajak.

Hal ini disebabkan kebijakan pajak memuat nilai dan tujuan yang ada pada kebijakan fiskal dan kebijakan publik. Kebijakan fiskal adalah seluruh kebijakan pemerintah yang memiliki keterkaitan dengan aspek finansial, yang utamanya bertujuan untuk memenuhi kebutuhan anggaran dan menciptakan 
stabilitas ekonomi (Soemitro, 1986). Kebijakan publik adalah kebijakan yang dirumuskan dan diimplementasikan oleh pemerintah dengan tujuan utama untuk memberikan manfaat kepada publik (Rabin, 2003). Berdasarkan hal ini, maka kebijakan pajak merupakan kebijakan pemerintah yang memiliki tujuan ekonomis, yaitu untuk memenuhi kebutuhan anggaran negara dari sektor pajak, sekaligus untuk memberikan manfaat kepada publik.

Namun sesuai dengan pengertian pajak menurut undang-undang, maka manfaat yang akan diberikan kepada publik oleh negara atas pajak yang dibayarkan oleh wajib pajak bukan merupakan manfaat yang secara langsung dapat diterima oleh wajib pajak. Manfaat tersebut dapat berupa penciptaan kehidupan ekonomi yang stabil atau berupa pembangunan fasilitas publik. Meskipun demikian, sifat manfaat yang tidak langsung dari pajak yang dibayarkan sering menjadi pangkal permasalahan terkait kepatuhan wajib pajak. Dalam artian, wajib pajak tetap memandang bahwa kewajiban pajak adalah beban yang secara pasti dapat mengurangi keuntungan atau pendapatannya, sehingga sebagian wajib pajak mengambil sikap untuk tidak mematuhi kebijakan perpajakan (Daniel \& Meliala, 2009).

Menciptakan kepatuhan tinggi pada wajib pajak merupakan tujuan utama dari keberadaan otoritas pajak atau Direktorat Jenderal Pajak (DJP). Melalui fungsi dasar, fungsi pendukung, dan fungsi utamanya, DJP berupaya memastikan bahwa wajib pajak patuh terhadap seluruh kebjakan perpajakan yang ada di Indonesia (Kemenkeu, 2017). Meskipun data menunjukkan bahwa tingkat kepatuhan wajib pajak terus meningkat dari tahun ke tahun, namun rendahnya tax ratio Indonesia menggambarkan bahwa kepatuhan wajib pajak sebenarnya masih belum optimal. Selain itu, rendahnya tax ratio juga menunjukkan adanya celah lebar yang harus ditutupi untuk dapat mengoptimalkan penerimaan pajak negara. Celah atau kekurangan tersebut terletak pada kurangnya upaya otoritas pajak untuk melaksanakan tugas pemungutan pajak, yang dalam jangka pendek berdampak pada kurang optimalnya penerimaan pajak negara dan dalam jangka panjang berpotensi menyebabkan penurunan tingkat kepatuhan pajak (Farouq, 2018).

Dengan demikian, maka penciptaan perilaku patuh wajib pajak terhadap peraturan perpajakan selayaknya menjadi pangkal sekaligus ujung dari kebijakan pajak pemerintah. Dalam artian, peningkatan kepatuhan wajib pajak perlu menjadi sasaran dari kebijakan pajak pemerintah karena adanya permasalahan terkait kurangnya kepatuhan wajib pajak, dan lebih daripada itu, kepatuhan wajib pajak juga merupakan faktor utama yang dapat mendorong pada tercapainya penerimaan pajak negara yang optimal.

Keterhubungan antara kepatuhan wajib pajak dan kebijakan pajak dapat dijadikan sebagai kerangka konseptual dalam formulasi dan penetapan kebijakan pajak. Menurut Hallsworth, Parker, dan Rutter (2011), formulasi masalah merupakan tahapan yang dilakukan dengan tujuan untuk mengetahui permasalahan yang sedang dihadapi, penyebab dari munculnya permasalahan tersebut, dan kedudukan pemerintah dalam mengatasi masalah tersebut. Dalam konteks perpajakan, maka perumusan kebijakan pajak untuk mengatasi permasalahan terkait kurangnya kepatuhan wajib pajak dapat dilakukan dengan mempertimbangkan faktor-faktor yang mempengaruhi kepatuhan wajib pajak. 
Sebagaimana disebutkan sebelumnya, faktor yang mempengaruhi perilaku patuh wajib pajak terdiri dari faktor internal dan faktor eksternal. Faktor internal adalah faktor yang berasal dari dalam diri wajib pajak, yang dapat berupa kepercayaan wajib pajak terhadap pemerintah dan hukum dan pengetahuan wajib pajak terhadap regulasi perpajakan. Faktor eksternal adalah faktor yang berasal dari luar diri wajib pajak, yang dapat berupa adanya penegakan sanksi pajak yang adil dan jelas dan pelaksanaan sosialisasi perpajakan oleh otoritas pajak.

Faktor internal dan eksternal tersebut sebenarnya memiliki keterikatan erat antara satu sama lain. Faktor internal wajib pajak, yaitu kepercayaan dan pengetahuan wajib pajak dapat terbentuk ketika pemerintah dapat menciptakan faktor eksternal, yaitu penegakan sanksi pajak dan sosialisasi perpajakan dengan efektif dan efisien. Wajib pajak akan dapat memiliki pengetahuan perpajakan yang baik jika pemerintah mampu melaksanakan sosialisasi perpajakan yang tepat sasaran. Selain itu, penegakan sanksi hukum dan segenap peraturan perpajakan akan membuat wajib pajak memiliki wawasan bahwa pemerintah benar-benar serius dalam memberlakukan peraturan perpajakan, yang dalam jangka panjang akan menumbuhkan kepercayaan wajib pajak terhadap integritas pemerintah dalam bidang perpajakan. Tingkat kepatuhan wajib pajak yang semakin tinggi akan mendorong pada penerimaan pajak negara yang semakin optimal dan pada akhirnya akan menjadi penggerak pertumbuhan ekonomi secara berkelanjutan.

Model hubungan antara kepatuhan wajib pajak dan faktor-faktor yang mempengaruhinya dapat dilihat pada Gambar 2.

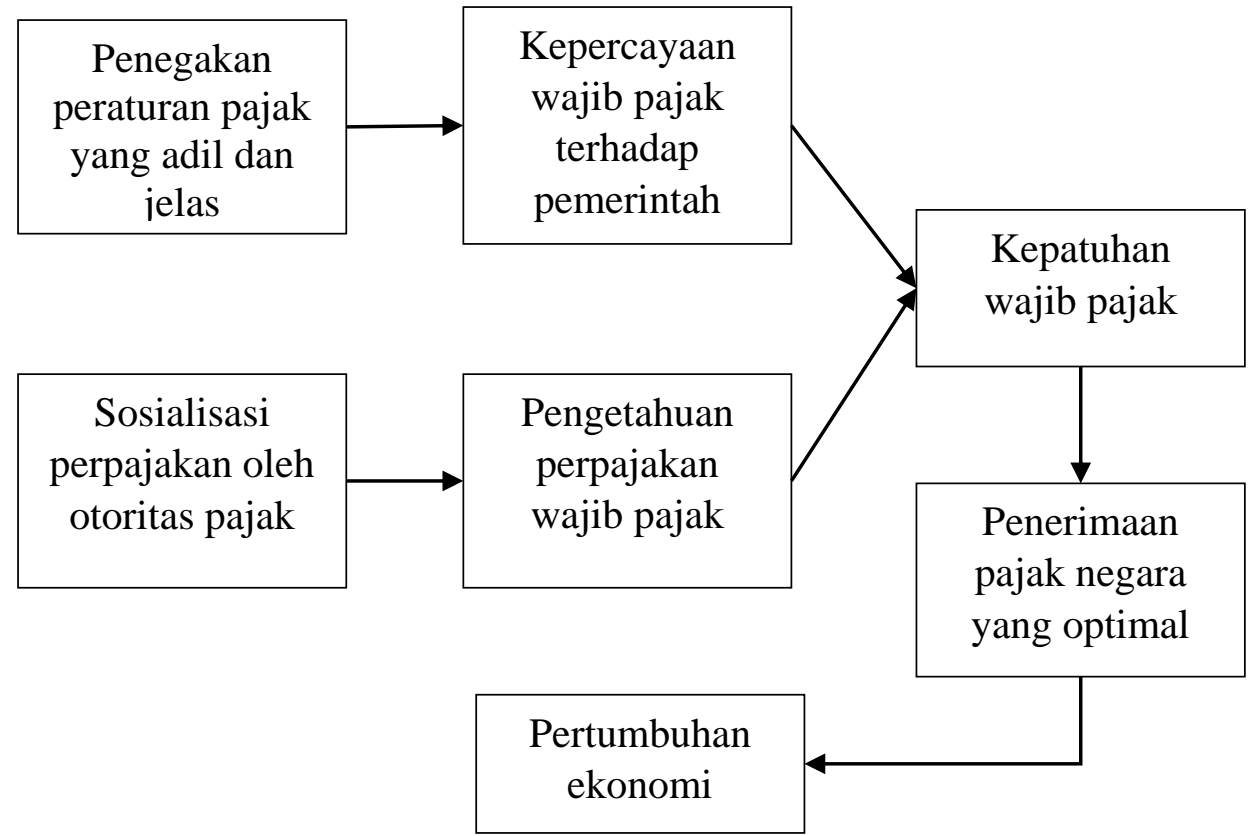

Gambar 2. Model Hubungan antara Kepatuhan Wajib Pajak dan Faktor-Faktor yang Mempengaruhinya

Sumber: Hallsworth, Parker, \& Rutter, 2011

Gambar 2. menunjukkan bahwa masalah kepatuhan wajib pajak dapat berawal dari adanya masalah kepercayaan dan pengetahuan wajib pajak, yang 
disebabkan karena adanya masalah pada penegakan peraturan pajak dan pada sosialisasi perpajakan oleh pemerintah. Dengan demikian, kebijakan pajak yang paling tepat untuk diterapkan untuk meningkatkan kepatuhan wajib pajak adalah kebijakan yang dapat mendorong pelaksanaan penegakan pajak menjadi lebih adil dan jelas, serta kebijakan yang mampu meningkatkan efektivitas dan efisiensi sosialisasi perpajakan kepada wajib pajak. Dengan kata lain, masalah kepatuhan wajib pajak tidak dapat hanya dilihat sebagai kekurangan atau kesalahan pada diri wajib pajak. Pemerintah sebagai otoritas pajak justru menjadi pihak yang harus aktif berbenah untuk mengatasi masalah ini. Pembenahan internal pemerintah tidak hanya akan dapat mengatasi permasalahan kepatuhan wajib pajak yang kurang maksimal, namun juga akan meningkatkan integritas pemerintah di mata masyarakat.

\section{SIMPULAN}

Berdasarkan hasil penelitian di atas dapat diambli kesimpulan yang dapat antara lain; pertama, faktor yang mempengaruhi perilaku patuh wajib pajak dapat dibagi menjadi dua, yaitu faktor internal dan faktor eksternal. Faktor internal adalah faktor yang berasal dari dalam diri wajib pajak, yang dapat berupa kepercayaan wajib pajak terhadap pemerintah dan hukum dan pengetahuan wajib pajak terhadap regulasi perpajakan. Faktor eksternal adalah faktor yang berasal dari luar diri wajib pajak, yang dapat berupa adanya penegakan sanksi pajak yang adil dan jelas dan pelaksanaan sosialisasi perpajakan oleh otoritas pajak.

Kedua, peningkatan kepatuhan wajib pajak perlu menjadi sasaran dari kebijakan pajak pemerintah karena adanya permasalahan terkait kurangnya kepatuhan wajib pajak, dan lebih daripada itu, kepatuhan wajib pajak juga merupakan faktor utama yang dapat mendorong pada tercapainya penerimaan pajak negara yang optimal. Kebijakan pajak yang paling tepat untuk diterapkan untuk meningkatkan kepatuhan wajib pajak adalah kebijakan yang dapat mendorong pelaksanaan penegakan pajak menjadi lebih adil dan jelas, serta kebijakan yang mampu meningkatkan efektivitas dan efisiensi sosialisasi perpajakan kepada wajib pajak.

Di sisi lain, penelitian tersebut tidak lepas dari kekurangan dan kelemahan sehingga untuk menindaklanjuti temuan penelitian ini, terutama terkait dengan faktor-faktor yang mempengaruhi kepatuhan wajib pajak. Analisis lebih lanjut dapat menggunakan pendekatan kuantitatif agar dapat menemukan hasil berbasis data primer yang dapat diuji validitas dan reliabilitasnya secara statistik, sehingga dapat melengkapi temuan penelitian ini.

\section{REFERENSI}

Ajzen, I., \& Fishbein, M. (1975). Belief, Attitude, Intention, and Behavior. An Introduction to Theory and Research, (129), 385.

Anggraini, F. (2015). Faktor - Faktor Yang Mempengaruhi Kepatuhan Wajib Pajak Orang Pribadi. Sosio E-Kons, 7(3), 196-203.

Daniel, A. L., \& Meliala, A. (2009). Mengintip Kiprah Konsultan Pajak di Indonesia. Jakarta: Murai Kencana.

Farouq, M. S. (2018). Hukum Pajak di Indonesia. Jakarta: Penerbit Kencana. 
Febriyani, Y., \& Kusmuriyanto. (2015). Analisis Faktor-Faktor Yang Mempengaruhi Kepatuhan Wajib Pajak. Accounting Analysis Journal, 4(4), 1-10.

Hallsworth, M., Parker, S., \& Rutter, J. (2011). Policy Making In The Real World Evidence and Analysis. USA: McGraw-Hill.

Heider, F. (1958). The Psychology of Interpersonal Relations. New York: Wiley.

Istijanto. (2010). Riset Sumber Daya Manusia. Jakarta: Gramedia Pustaka Ilmu.

Kemenkeu. (2017). Laporan Tahunan 2011-2017. Jakarta.

Kementrian Keuangan Republik Indonesia. (2018). Laporan Tahunan 2011-2017. In Laporan Tahunan. Jakarta: Kemetrian Keuangan Republik Indonesia.

Listyowati, Samrotun, Y. C., \& Suhendro. (2018). Faktor-Faktor yang Mempengaruhi Kepatuhan Wajib Pajak dalam Membayar Pajak. Jurnal Riset AKuntansi Dan Bisnis Airlangga, 3(1), 372-395.

Luthans, F. (2005). Organizational Behavior. New York: McGraw-Hill.

Mardiasmo. (2009). Perpajakan. Yogyakarta: Andi.

Moleong, L. J. (2012). Metode Penelitian Kualitatif Cet, Ke-30. Jakarta: Remaja Rosdakarya.

Primasari, N. H. (2016). Faktor-Faktor yang Mempengaruhi Kepatuhan Wajib Pajak Orang Pribadi yang Melakukan Pekerjaan Bebas. Jurnal Akuntansi Dan Keuangan, 5(2), 180-199.

Rabin, J. (2003). Encyclopedia of Public Administration and Public Policy. New York: Marcell Dekker, Inc.

Rahayu, N. (2017). Pengaruh Pengetahuan Perpajakan, Ketegasan Sanksi Pajak, dan Tax Amnesty terhadap Kepatuhan Wajib Pajak. Akuntansi Dewantara, 1(1), 15-30.

Razak, A. A., \& Adafula, C. J. (2013). Evaluating Taxpayers Attitude And Its Influence On Tax Compliance Decisions In Tamale, Ghana. Journal of Accounting and Taxation, 5(3), 48-57.

Robbins, S. P., \& Judge, T. A. (2008). Perilaku Organisasi. Jakarta: Salemba Empat.

Siat, C. C., \& Toly, A. A. (2013). Faktor-Faktor Yang Mempengaruhi Kepatuhan Wajib Pajak Dalam Memenuhi Kewajiban Membayar Pajak Di Surabaya. Tax and Accounting Review, 1(1), 41-48.

Soemitro, R. (1986). Pajak Penghasilan. Bandung: Eresco.

Suartana, I. W. (2012). Akuntansi Keperilakuan. Jakarta: Andi.

Supriyono, R. A. (2018). Akuntansi Keperilakuan. Yogyakarta: Gajah Mada University Press.

Susanto, E. (2002). Perilaku Wajib Pajak dalam memahami Pentingnya Membayar Pajak. Jurnal Perpajakan Indonesia, 2(2), 19-24.

Syakura, M. A., \& Yoremia, L. G. (2017). Perilaku Wajib Pajak terhadap Niat Menggunakan E-Filing dan Kepatuhan Wajib Pajak (Studi pada Wajib Pajak dengan Profesi sebagai Dosen). Akuntanbel, 14(1), 46-56.

Uli, Y. A. (2019). Pelaporan SPT Baru 61,7\%, Tingkat Kepatuhan Wajib Pajak Rendah. Retrieved December 22, 2019, from Okezone website: https:/ /economy.okezone.com/read/2019/04/02/20/2038285/pelapo ran-spt-baru-61-7-tingkat-kepatuhan-wajib-pajak-rendah

Wibowo, W. (2011). Cara Cerdas Menulis Artikel Ilmiah. Jakarta: Penerbit Buku Kompas. 
Wicaksono, R. A., Nazar, M. R., \& Kurnia, S. A. B. (2018). Pengaruh Sanksi Perpajakan, Kualitas Pelayanan, dan Pengetahuan Wajib Pajak terhadap Kepatuhan Wajib Pajak. E-Proceeding of Management, 5(1), 820-827.

Worldbank. (2019). Tax Revene (\% of GDP). Washington: Worldbank. 